\title{
MLL/GMPS Fusion Gene
}

National Cancer Institute

\section{Source}

National Cancer Institute. MLL/GMPS Fusion Gene. NCI Thesaurus. Code C99325.

A fusion gene that results from a chromosomal translocation $\mathrm{t}(3 ; 11)(\mathrm{q} 25 ; \mathrm{q} 23)$ which fuses either exon 7 or 8 of the MLL gene to nucleotide 150 of the GMPS gene. This rearrangement is associated with treatment-related acute myeloid leukemia. 